\title{
Efficiency of BacT/Alert in detecting Salmonella
}

Ida Parwati, Endang Samaun

\begin{abstract}
Abstrak
Untuk mengetahui efisiensi BacT/Alert, suatu otomatisasi yang digunakan dalam bidang mikrobiologi, kami membandingkan sensitivitas dan waktu yang diperlukan dari biakan empedu dan Fan BacT/Alert yang memiliki Ecosorb yang dapat menetralisasi materi toksik yang dapat mempengaruhi pertumbuhan bakteri. Dari 40 biakan darah, 16(40\%) positif dengan BacT/Alert, 12 (30\%) Salmonella dan 4 (10\%) bukan Salmonella. Sedangkan dengan biakan empedu didapatkan 10 (25\%) positif, 8(20\%) Salmonella dan 2 (5\%) bukan Salmonella. Waktu rata-rata yang dibutuhkan untuk mendeteksi pertumbuhan bakteri menggunakan BacT/Alert ialah 15,6 jam sedangkan dengan biakan empedu 57,6 jam. Wakı rata-rata yang dibutuhkan untuk identifikasi Salmonella menggunakan BacT/Alert ialah 66 jan sedangkan biakan empedu 78 jam. BacT/Alert merupakan metoda otomatis yang lebih sensitif dan efisien dalam mendeteksi pertumbuhan bakteri.
\end{abstract}

\begin{abstract}
To find out the efficiency of BacT/Alert, an automation in microbiological field, we compared the sensitivity in Salmonella detection and the time consumed by Gall culture and by Fan Bact/Alert which had an Ecosorb that could neutralized toxic material which could affect bacterial growth. From 40 blood cultures, 16 (40\%) positive by BacT/Alert, 12 (30\%) were Salmonella and 4 (10\%) were non Salmonella. By Gall culture $10(25 \%)$ were positive: $8(20 \%)$ were Salmonella and $2(5 \%)$ were non Salmonella. The mean time consumed for detection of bacterial growth by BacT/Alert was 15.6 hours and by Gall culture were 57.6 hours. The mean time consumed to identify Salmonella by BacT/Alert were 66 hours and by Gall culture were 78 hours. BacT/Alert is an automatic method that is more sensitive and efficient in detecting bacterial growth.
\end{abstract}

Dept. of Clin Pathology Padjadjaran University

Dr. Hasan Sadikin General Hospital Bandung, Indonesia 